\title{
PISANIE ZAGŁADY \\ W LITERATURZE WĘGIERSKIEJ PO 1989 ROKU. CASUS MIHÁLYA KORNISA (PODANIE) ${ }^{1}$
}

\author{
KINGA PIOTROWIAK-JUNKIERT ${ }^{2}$ \\ (Uniwersytet im. Adama Mickiewicza w Poznaniu)
}

\begin{abstract}
Słowa kluczowe: literatura węgierska po 1989, Mihály Kornis, Zagłada, literatura żydowska na Węgrzech
\end{abstract}

Key words: Hungarian literature after 1989, Mihály Kornis, genocide, Jewish literature in Hungary

\begin{abstract}
Abstrakt: Kinga Piotrowiak-Junkiert, PISANIE ZAGŁADY W LITERATURZE WĘGIERSKIEJ PO 1989 ROKU. CASUS MIHÁLYA KORNISA (PODANIE). „PORÓWNANIA” 14, 2014, T. XIV, s. 83-98. ISSN 1733-165X. W pierwszej części artykułu autorka prezentuje kilka kluczowych wydarzeń w obrębie węgierskiej kultury i polityki, mających związek z sytuacją Żydów po przełomie w 1989 roku. Przedmiotem rozważań jest nowela pt. Podanie Mihálya Kornisa z tomu Végre élsz (Nareszcie żyjesz). Pisarz należy do grupy aktywnych twórców żydowskich, ktorzy stworzyli kanon literatury węgierskiej. Kornis, świadomy sytuacji i kondycji pisarstwa poświęconego sytuacji Żydów i ich historii na Węgrzech, łamie gatunkowe i estetyczne tabu tworzy ironiczną nowelę, przełamującą stereotyp pisania o Shoah. Dzięki konceptowi detabuizacji udaje mu się stworzyć unikatowe, oryginalne świadectwo żydowskiego losu.
\end{abstract}

Abstract: Kinga Piotrowiak-Junkiert, THE WRITING OF THE SHOAH IN HUNGARIAN LITERATURE AFTER 1989. THE CASE OF MIHÁLY KORNIS (APPLICATION). "PORÓWNANIA" 14, 2014, Vol. XIV, p. 83-98. ISSN 1733-165X. In the first part of the article the author presents a few crucial cultural and political events, which have an association with the situation of Jews after the breakthrough of 1989. The subject of the article is the story entitled Application by Mihály Kornis from his book You live at last (Végre élsz). The writer belongs to the active Jewish authors. They have created a new canon of Hungarian literature. Kornis, who was aware of the

\footnotetext{
${ }^{1}$ Praca naukowa finansowana $w$ ramach programu Ministra Nauki i Szkolnictwa Wyższego pod nazwą "Narodowy Program Rozwoju Humanistyki w latach 2012-2014” w ramach projektu badawczego numer: NPRH 12H 11001880.

${ }^{2}$ Correspondence Address: kinga.piotrowiak@gmail.com
} 
situation and condition of Jews and their history in Hungary, breaks specific stereotypes of typical writing about Shoah. As a result of the De-Tabooisation concept he successfully creates a unique and original testimony of Jews' fate.

\section{ARTYKULACJA MILCZENIA. „KWESTIA ŻYDOWSKA" PO 1989 ROKU NA WĘGRZECH}

Géza Komoróczy³ zagadnieniu „kwestii żydowskiej” (zsidó kérdés) po 1989 roku poświęca zaledwie krótki fragment swojej monumentalnej pracy pt. Historia Żydów na Wegrzech (2012)4, wskazując tylko te epizody kulturowe i polityczne, które w największej mierze wymodelowały sytuację Żydów na Węgrzech po przemianie ustrojowej: brak oficjalnych przeprosin ze strony państwa węgierskiego (z pominięciem symbolicznego gestu pojednania Alberta Bereczky'ego $^{5}$ oraz wystąpienia ministra spraw wewnętrznych, Balázsa Horvátha, na brzegu Dunaju, w miejscu rozstrzelania węgierskich Żydów przez strzałokrzyżowców), związki dyplomatyczne z Izraelem ${ }^{6}$ oraz radiowe wystąpienie Istvána Csurki, w którym pisarz i zarazem jeden z czołowych polityków partii MDF (Magyar Demokrata Forum)7 , wypowiedział znamienne słowa, sugerujące, że teraźniejsza sytuacja polityczna ma niepokojąco wiele wspólnego z czasami Béli Kuna, gdy społeczeństwo węgierskie zostało bezwzględnie podporządkowane komunistycznemu terrorowi spod znaku bojówek militarnych, o nazwie „chłopcy Lenina” [Lenin-fiúk]. W kontekście omawianego problemu istotny jest

${ }^{3}$ Géza Komoróczy (ur. 1937) - orientalista, hebraista, asyrolog i historyk, założyciel Pracowni Judaistyki w Węgierskiej Akademii Nauk i Katedry Hebraistyki na Uniwersytecie im. L. Eötvösa w Budapeszcie. Autor prac z zakresu tradycji, kultury sumeryjskiej oraz historii Żydów: Żydowski Budapeszt. Zabytki, obrzędy, historia, I-II (1995), Hebrajskie mity i legendy (O Biblii) (2000), Hebrajskie materiały źródtowe do historii Wegier i węierskiego żydostwa od początków do 1686 roku (2003).

${ }^{4}$ G. Komoróczy, A zsidók története Magyarországon. Pozsony 2012. Dzieło badacza składa się z dwóch części, które noszą następujące podtytuły: tom pierwszy: Od średniowiecza do 1849 roku; tom drugi: Od 1849 roku do czasów wspótczesnych.

${ }^{5}$ A. Bereczky w 1946 roku wygłosił w imieniu kościoła reformatorskiego na Węgrzech słowa samokrytyki, potępiając wszelkie formy postępowania antyżydowskiego na Węgrzech i prosząc naród żydowski o przebaczenie win wojennych i zaniedbań, które nałożyły na Węgrów ciężar odpowiedzialności za zbrodnie popełnione przeciwko Żydom. Treść tego oświadczenia podaję za: G. Komoróczy, A zsidók története Magyarországon, t. 1, s. 888.

${ }^{6} \mathrm{~W}$ gronie najbardziej zasłużonych przedstawicieli państwa Izrael, którzy współtworzyli relację izraelsko-węgierską znaleźli się: Mose Arens (izraelski minister spraw zagranicznych), Shlomo Marom (ambasador Izraela na Węgrzech w latach 1989-1990), David Kraus (ambasador Izraela na Węgrzech w latach 1991-1994). Budapeszt stał się ważnym miejscem spotkań dyplomatycznych także dla Shimona Peresa, Yitzaka Shamira, Chaima Herzoga, Moshego Katzava. Zob. G. Komoróczy, A zsidók története..., s. 1055-1056.

${ }^{7}$ Węgierskie Forum Demokratyczne. 
fakt, że tej quasi-militarnej grupie przewodził fanatyczny morderca żydowskiego pochodzenia, namaszczony przez Kuna Tibor Szamuely [Tibor Szamuelly], nawołujący do „uświęcającego naród" rozlewu krwi i obiecujący obywatelom „wytępięnie" [kiirtani] wszystkich przedstawicieli burżuazji ${ }^{8}$. Sam koncept porównania przedstawicieli mniejszości żydowskiej na Węgrzech i ich udziału w życiu publicznym i politycznym z samozwańczymi, ludobójczymi(!) praktykami komunistycznego zbrodniarza w rażący sposób naruszył normy dziennikarskiego i etycznego decorum. Antyżydowskie wystąpienie I. Csurki (wyemitowane 14 stycznia 1990 na antenie Radia Kossuth w prawicowej audycji „Vasárnapi Újság” [Niedzielne Nowiny]) wywołało silny sprzeciw środowisk żydowskich, które wymusiły na redaktorze oficjalne zdefiniowanie jego światopoglądu' ${ }^{9}$.

Komoróczy nie pomija również tematu debat publicznych i społecznych, poświęconych powojennej „kwestii żydowskiej”, którym przewodzili ważni i uznani przedstawiciele życia intelektualnego na Węgrzech, dowodząc, że bycie Żydem pamiętającym dramatyczne wydarzenia Zagłady oznacza brak możliwości zrozumienia narodu węgierskiego i jego historycznych klęsk (Sándor Csoóri) ${ }^{10}$, że władza polityczna po 1989 roku znalazła się w rękach zasymilowanych Żydów ${ }^{11}$, a komunizm był wielkim aktem żydowskiej zemsty za Zagładę w czasie II wojny światowej (István Benedek). Wszystkie te postulaty, które Komoróczy ilustruje fragmentami wypowiedzi Ferenca Szálasiego ${ }^{12}$ i Gyuli Gömbösa13, rodziły konkluzję obecną w świadomości węgierskiej już od XIX wieku: najlepszym rozwiązaniem niewygodnej relacji węgiersko-żydowskiej powinien być nowy ruch syjonistyczny.

${ }^{8}$ Fragmenty wystąpień T. Szamuelly zostały zebrane w tomie: Szamuely Tibor válogatott cikkei (1908-1915) (Budapest 1969) oraz w: Összegyüjtött irások és beszédek (Budapest 1975)

${ }^{9}$ Antyżydowskie wystąpienie I. Csurki (wyemitowane 14 stycznia 1990 na antenie Radia Kossuth w prawicowej audycji „Vasárnapi Újság” [Niedzielne Nowiny]) poskutkowało silnym sprzeciwem środowisk żydowskich, które wymusiły na redaktorze oficjalne zdefiniowanie swojego światopoglądu. Csurka zapewniał, że nie ma nastawienia antysemickiego i nie jest przeciwny Żydom, pod warunkiem, że są ortodoksyjnymi wyznawcami wiary. Komoróczy puentuje „czytaj: którzy są zupełnie odseparowani od społeczeństwa węgierskiego a najlepiej traktuje tych, którzy wyjechali do Izraela". Treść słów redaktora i wiedzę o okolicznościach towarzyszących omawianej audycji podaję za G. Komoróczy, op.cit., t. 2, s. 1056-1057.

10S. Csoóri (ur. 1930) - poeta, scenarzysta, eseista; współzałożyciel MDF (Węgierskiego Forum Demokratycznego). Ibidem, s. 1059.

${ }^{11}$ W 2001 roku Imre Kertész, obserwujący przemiany polityczne, dokonujące się w obrębie węierskich partii politycznych, pisze o przejmowaniu władzy z rąk żydowskich polityków przez nową generację inteligencji. I. Kertész, Mentés másként. Feljegyzések 2001-2003. Budapest 2011, s. 5.

${ }^{12}$ F. Szalási (1897-1946) - premier Węgier (1944-45), przywódca faszystowskiej organizacji „,strzałokrzyżowców" [Nyilaskeresztes Párt - Hungarista Mozgalom], odpowiedzialnej za czystki na tle etnicznym i egzekucje przedstawicieli mniejszości żydowskiej na Węgrzech; organizacja, której przewodził, rozstrzelała Żydów na brzegu Dunaju w 1944 roku.

${ }^{13}$ Gy. Gömbös [Jálfai Vitéz] (1886-1936) - premier Węgier w latach 1932-36, związany z rządem Miklósa Horthyego, jako pierwszy przywódca krajów europejskich odwiedział Hitlera, gdy ten pełnił funkcję kanclerza; zwolennik wprowadzenia antyżydowskich przepisów na Węgrzech. 
Miałby on - czego dowodził jeszcze w XIX wieku Győző Istóczy ${ }^{14}$ - zatrzymać proces wtapiania się Węgrów w tę niezmienną i konserwatywną narodowość, jaką są Żydzi. Istóczy posłużył się wymownym, biblijnym konceptem, sugerując, że to "Jonasz mógłby połknąć wieloryba" - a nie odwrotnie.

Rozważania dotyczące sytuacji Żydów po 1989 roku Komoróczy konkluduje stwierdzeniem: „po przemianie ustrojowej wrogość względem Żydów i werbalny antysemityzm stawały się z roku na rok coraz bardziej śmiałe i pozwalano sobie na coraz więcej"15, czego dowodem może być odnowienie prac zakazanego wcześniej Koleżeńskiego Związku Frontu Wschodniego, który w 1995 roku, w rocznicę urodzin Szálasiego, spalił w Debreczynie zwoje Tory. Innym potwierdzeniem ciągle żywej niechęci do narodu żydowskiego mogłyby być słowa Lóránta Hegedúsa, który nawoływał w 2001 roku do aktywnego i radykalnego wykluczenia Żydów ${ }^{16}$.

Czy można zatem powiedzieć, że historia Żydów na Węgrzech jest jedynie historią węgierskiego antysemityzmu? János Gyurgyák, historyk idei i redaktor pisma Századvég, które przeprowadziło w 1990 roku ankietę dotyczącą „kwestii żydowskiej" na Węgrzech, dostrzega w transformacji politycznej i kulturalnej po 1989 roku oznaki odradzającej się normalności, która przejawiła się pod postacią wzmożonej aktywności politycznej Żydów w obrębie partii politycznych ${ }^{17}$ oraz rozwoju instytucji związanych $\mathrm{z}$ życiem literackim i publicznym (należy tutaj wspomnieć najważniejsze z nich: Magyar Zsidó Kulturális Egylet/Węgierskie Żydowskie Stowarzyszenie Kulturalne; zainicjowanie pracy pism "Múlt és Jövő" oraz "Szombat”, a także wydawnictwa „Múlt és Jövo"” czy zawiązanie Pracowni Jaudaistycznej na Węgierskiej Akademii Nauk w Budapeszcie) ${ }^{18}$.

Gyurgyák, autor pracy pt. Kwestia żydowska na Wegrzech. Historia idei a polityka ${ }^{19}$, przywołuje brzmienie trzech, kluczowych dla omawianego tematu, pytań Istvána Bibó, przy pomocy których można ujawnić rzeczywistą kondycję społeczną wobec nierozwiązanego tematu rozliczenia z Zagładą. Pierwsze z nich dotyczy problemu ponoszenia odpowiedzialności przez społeczeństwo węgierskie

${ }^{14}$ Gy. Istóczy (1842-1915) - w 1875 roku zainicjował węgierski ruch antysemicki, podczas jednego z posiedzeń parlamentu; autor kilkunastu mów dotyczących kwestii żydowskiej na Węgrzech (dotyczących m.in. edukacji, syjonizmu, konsekwencji asymilacji Żydów w społeczeństwie węgierskim). Treść przemów sejmowych z lat 1872-1896 została opublikowana w 1904 roku, stając się „Biblią antysemicką" na Węgrzech. Ważniejsze pozycje: Istóczy Győző országgyülési beszédei, indítványai és törvényjavaslatai 1872-1896. Budapest 1904; A Magyar Antiszemita Párt megsemmisítése s ennek következményei. Budapest 1906; Istóczy Gyöző országgyülési beszéde a zsidókérdésról. Budapest 1942.

${ }^{15}$ G. Komoróczy, op.cit., s. 1062.

${ }^{16}$ Ibidem, s. 1062.

${ }^{17}$ SzDSz [Szabad Demokráták Szövetsége] - Związek Wolnych Demokratów i MSzP [Magyar Szocialista Párt] - Węgierska Partia Socjalistyczna.

${ }^{18} \mathrm{Na}$ temat przemian politycznych lat '80 i ‘90 pisze János Gyurgyák, w: Idem, Zsidókérdés Magyarországon. Politikai eszmetörténet. Budapeszt 2001, s. 600.

${ }^{19}$ Patrz przypis 16. 
za współudział w unicestwianiu rodaków żydowskiego pochodzenia. Drugie to pytanie o społeczne i kulturowe przyczyny antysemityzmu. Trzecie zmusza do pracy wyobraźni, domagając się wizualizacji przyszłości losu węgierskich Żydów, a zwłaszcza procesu asymilacji. Bibó (Kwestia żydowska na Wegrzech po 1944 roku, $1918)^{20}$ przedstawił własną interpretację powyższych zagadnień, analizując znane sobie fakty i konteksty po 1944 roku, dając tym samym znakomity asumpt do koniecznej, ale pod wieloma względami niemożliwej debaty narodowej. Z punktu widzenia niemal siedemdziesięciu lat dzielących nas od publikacji pracy Bibó, wskazane przez niego kręgi tematyczne ciągle domagają się rozstrzygnięcia. $\mathrm{Z}$ pewnym zrozumieniem można było traktować spowolnioną reakcję Węgrów w czasach powojennych i brak skutecznych prac rewizjonistycznych, które domagałyby się bezstronnych, nie poddawanych żadnym ideologizacjom debat ${ }^{21}$. Sytuacja odrodzenia politycznego i swobody obywatelskiej po 1989 roku znosi możliwość błahego usprawiedliwiania milczenia w kwestii Zagłady.

\section{"INWALIDZI NIEWŁAŚCIWEGO JĘZYKA" - „KWESTIA ŻYDOWSKA" A REPREZENTACJA LITERACKA}

Imre Kertész, analizujący w tomie esejów pt. Ja, inny. Kronika przemiany (1990) sytuację Węgier $\mathrm{u}$ progu nowej ery, porównuje nastroje społeczne do syreniego śpiewu, który niegdyś wiódł na pokuszenie dzielnych żeglarzy Odyseusza. Noblista zauważa istotną i niepokojącą właściwość nagłej swobody politycznej: najwyżej cenioną cnotą społeczną jest witalizm, który - jak można mniemać - ma odzwierciedlać prawdziwe wyzwolenie i odrodzenie skumulowanej energii intelektualnej, artystycznej czy wreszcie - wyznaniowej. Pisarz z rosnącym przerażeniem odczytuje nieme znaki pożądanej postawy moralnej. Jest nią utrwalanie, doskonale dotąd funkcjonującej, tendencji do zacierania pamięci i wszelkich jej śladów. Inaczej mówiąc: żeby móc funkcjonować w nowym, wyzwolonym społeczeństwie, należy całkowicie zneutralizować mimowolne rewizyjne i rozliczeniowe odruchy

${ }^{20}$ I. Bibó, Zsidókérdés Magyarországon 1944 után. W: Válogatott tanulmányok. Budapest 1986. Wskazane wydanie studium Bibó prezentuje wybór dzieł teoretyka i filozofa polityki. Po raz pierwszy omawiany tekst opublikowany został w piśmie „Válasz” w 1948 roku. W języku polskim ukazał się zbiór najważniejszych esejów politycznych Bibó [Nędza matych państw wschodnioeuropejskich, Przyczyny i dzieje niemieckiej histerii politycznej, Sens europejskiego rozwoju społecznego, Kwestia żydowska] w przekładzie Jerzego Snopka. I. Bibó, Eseje polityczne. Przełożył, opracował i wstępem opatrzył J. Snopek. Kraków 2012.

${ }^{21} \mathrm{Na}$ temat powojennych losów Żydów na Węgrzech pisze (niezwykle lapidarnie - nota bene jak większość badaczy, poruszających ten temat) Róbert Szabó Győri w pracy: A kommunizmus és a zsidóság az 1945 utáni Magyarországon. Budapest 2009, s. 340-356. Autor poświęca uwagę przede wszystkim polityce i nastawieniu społecznemu w latach ‘ 80 i ‘90, skupiając się głównie na konsekwencjach polityki Kádára. Obok pracy R. Győri wymienić należy także książkę Tamása Ungvári, Ahasverus és Shylock. A „zsidókérdés” Magyarországon. Budapest 1999. 
czy gesty. W przypadku takich pisarzy węgierskich jak Kertész, którzy torowali drogę literackim reprezentacjom granicznego doświadczenia Zagłady, właściwym przejawem witalizmu powinno być milczenie, czyli „duchowe, umysłowe i wreszcie fizyczne samobójstwo" 22. Zdaniem węgierskiego noblisty główną przyczyną powstania takiej zaskakującej sytuacji zaburzenia komunikacyjnego, dysfunkcyjnej blokady polegającej na koncepcie radykalnego odcięcia świadomości historycznej na rzecz pozornego wyzwolenia, jest nawykowe posługiwanie się językiem minionej epoki, zbudowanym ze sztucznych formuł, stereotypów i schematów. Kertész nazywa użytkowników takiego „niewłaściwego” języka „inwalidami” [rokkant], którzy "potrzebują pierwszej pomocy moralnej, jakby zrozumieli, że pod jego [języka - KPJ] zdewaluowanymi słowami (...) kryją się ich moralne obrażenia. Szczękają moralne protezy, postukują moralne kule, moralne wózki inwalidzkie toczą się, gdzie oczy poniosą"23.

Przytoczona wypowiedź Kertésza jest jedną z niewielu tak odważnych diagnoz sytuacji politycznej i społecznej po 1989 roku na Węgrzech. Słowa pisarza potraktować trzeba nie tylko jako głos uważnego obserwatora, ale także jako swoisty artystyczny manifest. Kertész o marginalizowaniu tematyki żydowskiej $w$ literaturze węgierskiej wie prawie wszystko $i$, jak sam twierdzi, gdyby nie został wyróżniony przez kapitułę nagrody noblowskiej, jego nazwisko pozostałoby znane jedynie w wąskim kręgu krytyków, związanych zawodowo $\mathrm{z}$ animowaniem twórczości pisarzy żydowskiego pochodzenia ${ }^{24}$.

Metafory, którymi posługuje się autor eseju Ja, inny, odnoszą się właściwie do większości tekstów poświęconych doświadczeniu Zagłady, ponieważ przed pisarzami węgierskimi, usiłującymi dać wyraz własnym doświadczeniom wojennego antysemityzmu, wyrósł nagle mur języka, który zupełnie uniemożliwił im komunikację na poziomie narracyjnego przekazu. Po 1989 roku - mimo pozornej „wolności słowa" - musieli odwoływać się do gatunków, stylizacji językowych, toposów kulturowych i struktur tekstowych, służących konceptualnemu kodowaniu treści zawartych $\mathrm{w}$ utworach albo, co równie absurdalne, bo przeczy pozorom wolności słowa: posługiwali się „niewłaściwym językiem”, imitując mowę moralnych inwalidów, o których pisze Kertész. Refleksję węgierskiego twórcy należałoby rozszerzyć o stosowną glossę: literackie reprezentacje, o których jest tutaj mowa, są w przeważającej większości 25 tekstami wyrosłymi na gruncie osobistych przeżyć autorów. Węgierscy pisarze, usiłujący zawrzeć w artystycznym tworzywie swoje

22 Ibidem, s. 8.

${ }^{23}$ Ibidem, s. 11.

${ }^{24}$ Por. I. Kertész, Dossier K. Przeł. E. Sobolewska. Warszawa 2008, s. 97.

${ }^{25}$ Węgierskich pisarzy Zagłady podzielić można według cezury pokoleniowej. Pierwszą grupę stanowią twórcy relacjonujący własne obozowe / wojenne przeżycia [np. I. Kertész, M. Radnóti] oraz tzw. "drugie pokolenie" stawiające czoła traumie przodków [np. M. Kornis, M. Vámos, G. T. Szántó, G. Schein]. 
wojenne doświadczenia, skazani byli na podporządkowanie się praktyce fikcjonalizowania przeszłości w taki sposób, by „uszkodzony” ideologicznie język mógł nazywać i odzwierciedlić ich intymne, prawdziwe przeżycia. Proces, który, mając za cel zmaganie się z naruszoną kondycją intelektualną i emocjonalną, opierał się na konstruowaniu „życiowej prawdy" i manifestowaniu głęboko tajonego bólu przy pomocy języka imitującego mowę systemu politycznego. Główne pytanie, które należy zatem postawić tej twórczości, brzmiałoby: czy możliwe jest tworzenia obozowej autobiografii w krzywych zwierciadłach środków artystycznych.

János Kőbányai ${ }^{26}$ - wieloletni redaktor pisma „Múlt és Jövő”, autor kilkunastu książek poświęconych kulturze i literaturze żydowskiej oraz kondycji współczesnego Izraela - traktuje praktyki artystyczne skupione wokół tekstowych reprezentacji doświadczenia obozów jako przejaw szczególnej relacji między biografią a literaturą, w której mamy do czynienia z koegzystencją realnych, choć odpowiednio przetworzonych artystycznie postaci („autorreprezentacyjnych" figur alter ego autorów) i miejsc (geograficznych lokalizacji naznaczonych traumą). Fakty historyczne oraz prywatny rejestr przeżywanych emocji splatają się, tworząc dzieło autobiograficzne. Pisze Kőbányai:

Autobiografia. Co to jest? Opowiadanie o tym, co się nam zdarzyło. A co zawiera? Opisy bohaterów lub konkretnego czasu i jego atmosfery. Wszystko to nanizane jest na korpus narracji. Ta historia to życie prywatne opowiadającego. To świadectwo. To życie samo zwracające się ku sobie, w którym świadczący wyciąga $\mathrm{z}$ własnej historii naukę, z zamiarem utrwalenia, czyli uczynienia swojego życia nieśmiertelnym? Na pewno nie. Autobiografia jest tylko przekrojem życia, rodzajem streszczenia, esencją (...) Zawiera nie tylko te fakty, które się wydarzyły, ale także te, które tylko on mógł zobaczyće ${ }^{27}$.

Powyższe słowa dotyczą analizy twórczości Imre Kertésza, ale z powodzeniem można je odnieść do całego fenomenu pisarstwa autobiograficznego, dotyczącego doświadczeń obozowych. Historia przedstawiana jako "obozowa fabuła”, jako forma "opowiadania tego, co się nam wydarzyło" (lub tego, co zdarzyło się przedstawicielom mniejszości żydowskiej) jest, jak to stwierdzono wyżej, prezentowana tak, by mogła się pomieścić w ramach tekstu. Inaczej mówiąc: historia jest skrojona na miarę jej literackiej reprezentacji28. Oznacza to, że każdy pisarz,

${ }^{26}$ Ważniejsze prace badacza, redaktora i wydawcy: Magyar siratófal (1990); Budapesti aggadák. A Holokauszt utáni irodalom (red., 1999); Minden hiábavalóság. A magyar zsidó próza száz éve (1848-1948) (red., 1999); A halott arcán növekvő szakáll. A magyar zsidó történet vége (2001), Jób dija. Háttér és recepció. Budapest 2003; Kertésznapló. Budapest 2003; Holokauszt mint elbeszélés. A hazugság helye (2005); Az apokalipszis képköltője. Imre Ámos (2005); A magyar-zsidó irodalom története. Kivirágzás és kiszántás (2012).

${ }^{27} \mathrm{~J}$. Kóbányai, A Holokauszt mint narratíva. W: A magyar-zsidó irodalom története. Kivirágzás és kiszántás. Budapest 2012, s. 261.

${ }^{28}$ Ważniejsze teksty omawiające zagadnienie tekstowej reprezentacji wydarzenia Shoah i problem „niewyrażalności” tego doświadczenia: P. Czapliński, Zagłada jako wyzwanie dla refleksji o literaturze, 
angażujący się $\mathrm{w}$ niezwykle trudny proces tekstowego rozliczania pamięci i docierania o sedna naruszonej egzystencji, musiał w konkretny sposób „sterować" procesem pisania, zgodnie z regułami wyznaczonymi przez „inwalidów niewłaściwego języka".

Jak zatem pogodzić przymus zacierania, zniekształcania, a nawet „wytwarzania" - tytułem licentia poetica - nowej prawdy o rzeczywistości historycznej $\mathrm{z}$ wewnętrznym imperatywem twórczym skoncentrownaym na pragnieniu prezentowania trudnej i zdecydowanie nieaprobowanej wiedzy o czasie minionym? Konsekwencje tak aporetycznego wyzwania miały znaczący wpływ na kształt węgierskiej prozy poświęconej granicznemu doświadczaniu „żydowskiej tożsamości" - poszukiwała ona, z zaskakującym skutkiem, zupełnie nowych płaszczyzn, na których literacka ekspresja mogła odnaleźć własne środki wyrazu, nie wykazujące punktów wspólnych z „uszkodzonym językiem ideologii”, o którym pisał Kertész. Twórcy sięgali po stabuizowane gatunki literackie, wykluczone lub przynajmniej niepożądane na genologicznej mapie obozowego pisarstwa: baśń (G. Németh, Zsidó vagy?, 2004)29, groteskę (G. T. Szántó, Lágermikulás, 2004)30, satyrę, alegoryczną przypowieść (G. Schein, Lázár, 2004)31 etc.

Casus Mihálya Kornisa, twórcy tzw. „drugiego pokolenia”, autora kilkanastu książek prozatorskich i sztuk dramatycznych ${ }^{32}$ pokazuje jednak, że projekt łączenia języka ideologii z pisarstwem roszczącym sobie prawo do relacjonowania intymnych szczegółów życia żydowskiej rodziny w wojennych i powojennych dekoracjach jest możliwy. Jeśli zgodzimy się z tezą Ágnes Heller, która twierdzi że "o literaturze żydowskiej możemy mówić wtedy, gdy pisarz zajmuje się w swoim dziele doświadczeniem żydowskim"33, to Kornisa należałoby określić mianem "pisarza żydowskiego". Temat Zagłady Żydów na Węgrzech pojawia się bezpośrednio $\mathrm{w}$ dwóch jego nowelach: miniaturze prozatorskiej Podanie [Kérvény]

„Teksty Drugie" 2004, nr 5, s. 15; A. Easthope, Holocaust i niemożność przedstawienia, „Res Publica Nowa” 1997, nr 11; A. Rykner, Holocaust - nikczemność (nie)przedstawiana. Przeł. B. Forsztęga, „Dialog” 2001, nr 7; M. Janion, Nie wiem. W: Żyjąc tracimy życie. Niepokojące tematy egzystencji. Warszawa 2001, s. 397.

${ }^{29}$ G. Németh, Zsidó vagy? Pozsony 2004. Powieść Gábora Németha Zsidó vagy? (Jesteś Żydem?) utrzymana jest $\mathrm{w}$ konwencji baśni, prezentującej doświadczenia dziecięcego poznawania trudnej, żydowskiej tożsamości. Baśń i jej oniryczny koloryt niwelują czytelnicze odczucie grozy i dramatu istnienia.

${ }^{30}$ G. T. Szántó, Lágermikulás. Elbeszélesek. Budapest 2004.

31 G. Schein, Lázár. Pécs 2004.

${ }^{32}$ M. Kornis [właśc. Mihály Kertész] (ur. 1949) - autor książek Végre élsz (1981); Ki vagy te (1986); A félelem dicsérete (1989); Napkönyv (1994); Sóhajok hídja (1997); Pestis előtt (2003); Vigasztalások könyve (2005); Egy csecsemő emlékiratai (2007); Nekem az ég. Hazafutás (2009); Hol voltam, hol nem voltam (2011) i sztuk dramatycznych.

33 Á. Heller, Zsidótalanitás a magyar zsidó irodalomban. W: Pikareszk Auschwitz árnyékában. Budapest 2003, s. 12-13. 
z tomu Végre élsz (Nareszcie żyjesz) z $1980^{34}$ roku i w odrzuconym pierwotnie przez cenzurę, opublikowanym dopiero w 1989 roku Lamencie nad Dunajem (Dunasirató), poświęconym masakrze Żydów dokonanej przez strzałokrzyżowców nad brzegiem Dunaju w 1944 roku. Mimo że nowela, która będzie poddana analizie, została napisana przed transformacją ustrojową, jej ostateczny kształt formalny ukonstytuował się $\mathrm{w}$ trakcie poprawek do pierwszego wydania po czasach komunizmu z 1992 roku i z tego powodu została włączona do grupy tekstów reprezentujących literackie obrazy doświadczeń Zagłady po 1989.

W pierwszym z wymienionych tekstów Kornis wykorzystał oryginalny formularz urzędowy, odnaleziony w szufladzie ojca w 1974 roku. Był to pusty druk, dołączony do dokumentów, który - jak twierdzi pisarz w odautorskiej notatce ${ }^{35}$ został przesłany pocztą w latach sześćdziesiątych. Przy pomocy tego druku ojciec Kornisa miał dochodzić swoich praw do odszkodowania/rekompensaty szkód poniesionych wskutek Shoah na Węgrzech. Pisarz świadomie nadaje konceptualny, w pewien sposób „uwiarygodniony” kształt swojej noweli, podporządkowując treść Podania rygorowi języka i struktury urzędowego druku.

Załączam poniżej treść omawianej noweli:

\section{PODANIE}

Szanowna Dyrekcjo!

Ja, niżej podpisany, powołując się na słuszną sugestię zawartą w piśmie obiegowym (numer zgłoszenia: 1909-70; referent: Salkajowa), traktującym o konieczności dostarczenia Wykazu Roszczeń, załączam go wraz z niniejszym Oświadczeniem Uzupełniającym

\section{WYKAZ ROSZCZEŃ}

Na podstawie rozporządzenia o mocy prawnej z 1957 r. p.n.e (nr 40)

I. CZEGO ŻĄDA?

a) Chciałbym się urodzić 9 grudnia 1909 roku w Budapeszcie.

b) Żeby moją matką była Regina Weisz (gospodyni domowa), a ojcem Miksa Tábori (komiwojażer). (Jeśli Szanowna Dyrekcja nie może spełnić mojej prośby, w zakresie zaangażowania w tym celu wspomnianych osób, jestem otwarty na inne rozwiązania, byle bym tylko rozpoznał w zastępczych osobach Mamę i Tatę).

${ }^{34}$ Jak stwierdził Kornis w rozmowie z Zoltánem Farkasem, tekstowy korpus tomu był gotowy już w 1977 roku, w 1978 roku, po lekturze lektorskiej, został odrzucony ze względów politycznych (cenzorem był wówczas Endre Illés), ostatecznie tom ukazał się nakładem wydawnictwa Szépirodalmi Könyvkiadó w 1980 (zdaniem pisarza w 1981) roku. "Az író nem tür tovább: A kultúra hirtelen elhalgat”. Interjú Kornis Mihállyal. „168 Óra” 1992.06.02, s. 8-9. Zaskakującym wydaje się fakt, że Podanie, pierwsza nowela otwierająca debiutancką książkę Kornisa, mimo tak otwartej krytyki sytuacji politycznej i licznych zarzutów wobec władzy i stosowanych przez nią mechanizmów regulujących egzystencję ludzi, mogła ukazać się drukiem jeszcze przed transformacją ustrojową.

${ }^{35}$ M. Kornis, Kérvény. W: Végre élsz. Budapest 2006, s. 225. 
c) Proszę dalej, by moją żoną była Edit Fehér (aktorka, później na stanowisku odpowiedzialnej za wydatki), a moim synem Paweł Tábori (uczeń). (Patrz: uwaga do punktu I. b podana w nawiasie; tutaj słowa: „Mamę” i „Tatę" można zastąpić słowami „Żonę" i „Syna”).

d) Co się tyczy wnuków - z uwagi na spodziewaną datę mojej śmierci - (patrz punkt II) rezygnuję $\mathrm{z}$ ich posiadania raz na zawsze.

\section{JAK DŁUGO CHCE ŻYĆ?}

Proszę o życie trwające 61 lat 6 miesięcy 3 dni 2 minuty 17 sekund.

Podanie wręczałem Szanownej Dyrekcji już wielokrotnie - w latach ‘80 p.n.e., w 1241, 1514, 1526, 1711, 1849 - dotychczas odrzucano je jednak z powodu braku miejsc. Teraz proszę w dwójnasób. Co prawda w roku 1961 nie ma tych miejsc zbyt wiele, ale jeśli mógłbym liczyć na przychylność Szanownej Dyrekcji, zapewniam, że w danym mi czasie: będę żył.

\section{PO CO?}

a) Ponieważ chciałbym ukończyć sześć lat szkoły elementarnej, cztery klasy realnej i wyższą szkołę handlu. Później chętnie podjąłbym pracę w charakterze kasjera w zakładzie Haas i Syn, zajmującym się w 1939 roku - za zgodą Szanownej Dyrekcji - handlem futrami i mieszczącym się przy ulicy Królewskiej - później Majakowskiego - jako małe, samodzielne przedsiębiorstwo. Z kolei w 1940 roku spełniłbym swoje marzenie: kupiłbym dwuosobowy pojazd Topolino. (Przy rozpatrywaniu mojego wniosku, proszę wziąć pod uwagę, że tym właśnie autem zawiozę wkrótce Mamę do hali targowej, o czym nawet nie śmie marzyć!).

Zapotrzebowanie czasowe - sklep, jazda autem, zakupy, kąpiel - 3 lata.

b) W dalszej kolejności myślę też o II wojnie światowej.

Przyjmę na siebie: nazizm, antysemityzm; noszę: żółtą gwiazdę. Oddam swój samochód i sklep Węgierskiej Armii, dokładniej mówiąc: odpowiedniemu Organowi Tępienia Żydów w Ministerstwie Przemysłu i Handlu.

Szanowna Dyrekcjo: proszę tutaj - jeśli to tylko możliwe - żeby moich rodziców nie wywozić bydlęcym wagonem do obozu w Mauthausen, ponieważ wygląda na to, że mam szansę załatwić im miejsce $\mathrm{w}$ getcie na ulicy Dohány. Sobie życzę zesłania na prace przymusowe.

Pobicia, skakanie jak żabka - będę w tym mistrzem.

Mam nadzieję, że w 1945 roku ja i moja rodzina doczekamy wyzwoleńczego pochodu Armii Czerwonej - Patrz: punkt I i II - i jeśli tak się stanie: bezzwłocznie założę rodzinę, spłodzę dzieci i wstąpię do Węgierskiej Partii Pracy.

c) W latach 1945-1948: będę szczęśliwy.

Zapotrzebowanie czasowe: nowy sklep, nowy samochód, zakupy, kąpiel: 3 lata.

d) W 1949 roku chciałbym poznać mojego syna. Dobrze by się stało, gdyby w tym samym roku odebrano mi wreszcie samochód (do tego czasu pochowam Mamę), sklep i legitymację partyjną.

e) Żeby w podobny sposób wykluczono z partii moją żonę.

Gdyby zaistniały tu kłopoty natury technicznej, z uwagi na to, że moja żona będzie miała ciut za mało wspólnego z sektorem prywatnym, niechże będzie mi wolno zwró- 
cić szczególną uwagę Dyrekcji na osobę żony Józefa Csizmadiego, nazywaną Babirą. Śmiem twierdzić, że uda się ją nakłonić do napisania anonimowego listu, w którym poinformuje władzę, że moja żona terminowała przez sześć lat na ulicy Vörösmarty'ego w niższych klasach szkoły realnej w Zgromadzeniu Panien Szkockich, pozostając równocześnie, za sprawą Róży Klein, w ścisłych kontaktach z imperialistycznymi Stanami Zjednoczonymi Ameryki, skąd otrzymywała listy, czytała je i pisemnie na nie odpowiadała etc.

f) Żeby mojego syna nie przyjęto do przedszkola.

g) Nie wezmę udziału w kontrrewolucyjnych ruchach w 56-tym, przeciwnie - będę głodować na znak protestu, sprzeciwiając się ogólnemu chaosowi. Będę umiał sobie wyobrazić obecność służb porządkowych na klatce schodowej o czwartej nad ranem, i będę zarazem wdzięczny, gdy wspomniana wyżej Armia Czerwona znowu poda krajowi pomocną dłoń.

h) Począwszy od funkcji zastępcy intendenta, potem zaś jako intendent, chciałbym kontynuować, czyli w istocie: zakończyć swoje życie.

Uwaga:

Zwracam się z prośbą, by zostały pominięte konsekwencje znaczących wydarzeń historycznych poza tymi wyżej wymienionymi.

Z wyrazami szacunku: István Tábori

\section{Oświadczenie Uzupełniające}

Niżej podpisany, świadomy konsekwencji prawnych oznajmia: że jako drobny przedsiębiorca, kierowca ciężarówki, zastępca intendenta i intendent będzie użytecznym członkiem Królestwa Węgier, Węgierskiej Republiki Rad, Węgier potrianońskich, Regencji Apostolskiej, Wielkiej Ojczyzny Karpat i Dunaju, Węgierskiej Republiki Ludowej $\mathrm{i}$ innych.

Będę szanował zarządzenia Franciszka Józefa I, hrabiego Mihálya Károlyiego, Béli Kuna, Miklósa Horthy'ego, Macieja Rakosiego, Jánosa Kádara i innych oraz strzegł honorowo ich ustaw.

Wysłucham stojąc na baczność do ostatniej nuty hymnu austriackiego, niemieckiego, sowieckiego, węgierskiego, w dalszej kolejności także Gotterhalte, Giovienezzy, Eriki, "Jeśli Ziemia jest kapeluszem Boga”, jak również pieśni „Szózat”, ,Naprzód czerwoni, proletariusze" i Międzynarodówki.

Oddam należny szacunek austriackiej, niemieckiej, sowieckiej, narodowej i komunistycznej fladze, a co się tyczy naszego godła: podwójnemu krzyżowi, koronie świętego Stefana, sierpowi i młotowi, kłosom pszenicznym i innym.

Moich przełożonych - są nimi: Ödön Haas i Paweł Haas, Endreg Garzó Vitéz pułkownicy czasów winy i kary, dyrektor Kalman Zserci i przewodniczący spółdzielni Kalman Zserci junior - będę szanował w niemniejszym stopniu, będąc posłuszny wszystkim ich słowom. Zatroszczę się sumiennie o swoje obowiązki pracownicze i osobiste jedzenie, sen, planowanie podróży; bez słowa skargi będę pomagał żonie $\mathrm{w}$ pracach domowych, zmywaniu, sprzątaniu i wykręcaniu szmaty do mycia podłóg. 
W trakcie mojego życia nie będę niepokoił Szanownej Dyrekcji pytaniami o loty kosmiczne, rolę w filmie, o Hyde Park, pogodzę się natomiast ze śmiercią zanim przyjdzie lub wraz z jej nadejściem. I nie będę miał cudzych bogów, nie będę dawał fałszywego świadectwa przeciw memu bliźniemu, nie będę pożądał żony bliźniego swego, ani jego niewolnika, ani jego niewolnicy, ani wołu, ani osła, ani żadnej rzeczy, która jego jest.

Ufając, że moja prośba spotka się ze zrozumieniem, pozostaję tym, kim jestem:

István Tábori³6

Nawet pobieżna lektura powyższej noweli pozwala stwierdzić, że dominantą kompozycyjną Podania są mantryczne repetycje urzędowych zwrotów [„,Szanowna Dyrekcjo!", "Ja niżej podpisany" czy WYKAZ ROSZCZEŃ] oraz zachowanie oryginalnej struktury druku państwowego. Kornis przekroczył niewidzialne granice podyktowane przez ramy strukturalne i językowe "gotowego formularza", poszukując na jego obrzeżach własnych inspiracji. Węgierski twórca $\mathrm{z}$ artystyczną ostrożnością bada możliwości formalne (językowe) i strukturalne odnalezionej matrycy i przeszczepia $w$ jej obręb esencję ludzkiego istnienia. Formułowanie podania, czyli akt pisarski, staje się więc procesem polegającym na sztukowaniu prywatnego życia Istvána Tabori, głęboko tragicznym redukowaniu wielowymiarowej natury egzystencji, polegającym na wskazaniu kilku zaledwie granicznych doświadczeń, czyli w istocie na dopasowaniu tragicznej biografii bohatera do wymogów formalnych druku. Taka tekstowa synekdocha, konceptualny abstrakt ludzkiego istnienia pełnić ma przy tym podwójną rolę: wyliczając, czyli akcentując znaczenie węzłowych wydarzeń życia, ma równocześnie - a może przede wszystkim - niwelować ewentualne wrażenie "tekstowego rewizjonizmu”, obnażającego prawdę o funkcjonowaniu systemu komunistycznego.

Zadanie pisarskie, polegające na swoistej grze konwencjami (język urzędowy versus język ezopowy) opiera się więc na konieczności konceptualizowania wszelkich detali. Najtrudniejszym wyzwaniem jest skuteczne zatarcie szczegółów identyfikujących ramę temporalną, obejmującą opisywane życie wnioskującego bohatera. Kornis wykorzystuje daty wydarzeń (np. 1957), dołączając do nich antydatujące oznaczenie „p.n.e.”, które nie zniekształca jednak pierwotnego, czytelniczego gestu, polegającego na odruchowym osadzaniu prezentowanej fabuły w konkretnym tle historycznym. Tak stosowany zapis odpiera ewentualny zarzut krytyki władzy i pozwala Kornisowi zachować „artystyczną szczerość” konieczną, by uwiarygodnić dramat Tábori. Daty i ramy czasowe przywoływane w kolejnych partiach tekstu („1241, 1514, 1526, 1711 i 1849”) są wyliczone bez skrótowego

\footnotetext{
${ }^{36}$ Tłumaczenie prezentowanego tekstu, mojego autorstwa, zostało opublikowane po raz pierwszy na stronie Literackiego Koła im. A. Józsefa (JAK). M. Kornis, Podanie. Przeł. K. Piotrowiak-Junkiert. W: http://www.jozsefattilakor.hu/index.php?submenu=rendezvenyek\&id=1064\&details=1\&cat=4 (data dostępu: 17.09.2013).
} 
oznaczenia „év" lub „évben" (rok / w roku), można zatem je odczytać jako czterocyfrowe ciągi liczb, które dla węgierskiego czytelnika pozostają jednoznacznymi wskazaniami kluczowych klęsk historycznych. I tak, 1241 to data sromotnej klęski państwa Béli IV na polach Mohi, w czasie najazdu tatarskiego, 1514 - upadek powstania chłopskiego Dózsy, 1526 to data klęski wojsk węgierskich pod Mohaczem, 1711 - po początkowych sukcesach powstania Rakoczego, kraj ponownie wraca pod panowanie Habsburgów, 1849 - kończy się Wiosna Ludów. Co znamienne dla omawianej noweli, daty rewolucji 1956 roku i lat wojny (tutaj Kornis wymienia 1945, 1948) są zapisane bez wcześniejszego, „maskującego”, antydatującego oznaczenia.

István Tábori, narrator i autor składanego podania, przywołuje historyczne klęski, sugerując bardzo wymownie, że jest szczególnym wcieleniem historycznego everymana, obecnego w każdej porażce dziejowej. Bohater pokreśla wielość swoich historycznych wcieleń także w wykazie pieśni i hymnów, które śpiewa jako obywatel (m.in. Gotterhalte, Giovienezza, pieśn „Szózat”37 etc.), w wyliczeniu nazw symboli państwowych („Oddam należny szacunek austriackiej, niemieckiej, sowieckiej, narodowej i komunistycznej fladze, a co się tyczy naszego godła: podwójnemu krzyżowi, koronie świętego Stefana, sierpowi i młotowi [...]"), struktur państwowych i administracyjnych (m.in. Królestwo Węgier, Węgry potrianońskie etc.), a także imion panujących władców. Komponowanie takiej niejednorodnej pod względem ideologicznym, mozaiki emblematów symbolizujących kolejne etapy przemian dziejowych obserwowanych przez narratora ma jeden zasadniczy cel: Kornis akcentuje znaczenie pojedynczego, żydowskiego istnienia, które zbudowało własną świadomość i narodową tożsamość na fundamencie węgierskiej historii. W tekście Podania to, co prywatne (żydowskie), i to, co uniwersalne (węgierskie), zatraca swoje sztywne granice. Pozornie nieusuwalny status zmarginalizowanego, anonimowego (utajnionego) żydowskiego istnienia jest wyniesiony do rangi równoprawnego, $\mathrm{w}$ pełni wartościowego bytu. Tábori w takim samym stopniu, jak obywatele Węgier „nieżydowskiego” pochodzenia, identyfikuje się z krajem i wyraża pragnienie egzystencji w wolnym państwie. Swoistym ukoronowaniem tego konceptu jest zabieg pisarski, polegający na nadaniu narratorowi imienia i nazwiska, które stają się szczególną metaforą Węgier naznaczonych stygmatem Shoah. István (pol. Stefan) jest imieniem największego władcy $\mathrm{w}$ historii kraju, króla-ikony, archetypu niedościgłego monarchy, którego "mit obywatelski” przetrwał do czasów współczesnych. Nazwisko wnioskującego - Tábori - jest przymiotnikiem utworzonym od rzeczownika 'tábor' [obóz] i bezsprzecznie konotuje istnienie univers concentracionnaire. Podpis bohatera, wieńczący literacki manifest objęty ramami urzędowego formularza, potrakto-

37 Utwór M. Vörösmarthyego z 1826 roku. Tekst pełniący funkcję hymnu narodowego, do czasu uznania i uchwalenia hymnem narodowym dzieła F. Kölcseya z 1823 roku. 
wać można jako rodzaj deklaracji, dwuwyrazowej pieczęci, symbolicznie zaświadczającej o nierozerwalnym, choć trudnym do zrozumienia spleceniu żydowskiego i węgierskiego losu.

Kluczowym konceptem artystycznym zastosowanym przez Kornisa jest prezentowanie wszystkich partii tekstu, mających związek z ujawnianiem / manifestowaniem żydowskiej tożsamości narratora poprzez osadzanie ich na tle autoironicznym. Konieczne jest tutaj przypomnienie, że mówimy o wypełnianiu matrycy druku urzędowego i stylizacji, mającej na celu uwypuklenie przede wszystkim przestrzeganie reguł wyznaczanych przez oficjalny ton podania. Tego rodzaju wypowiedzi, z zasady zbudowane na fundamencie wzajemnego dystansu i zaznaczające wyraźnie granice pomiędzy wnioskującym podmiotem a organem państwowym, wykluczają możliwość zaistnienia ironii i wyrażeń o wydźwięku ironicznym w warstwie językowej. Jak stwierdził Michał Głowiński: „w pewnych gatunkach mowy zastosowanie ironii jest niemożliwe, bo wchodziłoby w konflikt z tym, co decyduje o ich przeznaczeniu i w jakiś sposób wyznacza istotę" 38 . Kornis łamie ten kod językowy, torując drogę najbardziej intymnym wyznaniom, które paradoksalnie - są "osłonięte” barierą ironicznych fragmentów tekstu. Narrator odważnie relacjonuje najbardziej dramatyczne przeżycia związane z żydowskich pochodzeniem: upokorzenia, tortury, przesłuchania, zaświadcza, że „będzie mistrzem w byciu pobitym, w skakaniu żabką", z chęcią pozbędzie się też swoich dóbr, przypnie żółtą gwiazdę do płaszcza, „przyjmie na siebie: antysemityzm i nazizm", ale ironiczny kod języka nie ma na celu - jak można by przypuszczać ujawnienia szczegółów dyskryminacji rasowej i religijnej. Przeciwnie, siła tych dramatycznych w swym wyrazie wyliczeń ogniskuje tekstową siłę wokół władzy, która w tak przejmujący sposób uformowała los narratora. Ironiczne tło Podania Kornisa zdradza ukryty koncept autora - Tábori w istocie nie prosi o los, ale o nim orzeka. Wypowiada się z auktoralnego punktu widzenia o własnym byciu zmarłym a nie, jak to ukazuje forma podania, człowieka projektującego swoje istnienie. Formuła narzucona przez podanie i wybór takiej struktury tekstu w pewnym sensie definiują pozycję człowieka wobec totalitarnego ustroju władzy, ale węgierski pisarz podkreśla głównie wagę szczegółu, który wymyka się „wielkiej retorcie władzy" - „osobności” narratora, będącej nieprzeniknionym bastionem i postawą samostanowienia o sobie.

Na podstawie decyzji wydawniczych możemy wnioskować, że zakodowany komunikat Kornisa nie został odczytany jako tekst naruszający spójność państwowej polityki wydawniczej, ale krytycy dostrzegli w debiutanckim tomie niezwykłą wartość literackiego tworzywa. András Pályi napisał na łamach "Jelenkor", w 1981 roku:

${ }^{38}$ M. Głowiński, Ironia jako akt komunikacyjny. W: Ironia. Red. M. Głowiński. Gdańsk 2002, s. 9. 
Moglibyśmy oczywiście powiedzieć o tym, jak nasz autor, zarówno jako nowelista, jak i dramatopisarz, daje wyraz imponującej gotowości do osiągnięcia mistrzostwa (...), posługuje się trikami i chwytami, które nie tylko wynalazł i odkrył dla swojej twórczości, ale które potrafi także urozmaicać; moglibyśmy powiedzieć również o tym, że te przeżycia - czy jak kto woli: ten wycinek świata - z którego pisarz czerpie - możemy nazwać etnicznym folklorem peszteńskiego żydostwa, jego socjologizowaniem. Tematem prawie nieobecnym w literaturze. Moglibyśmy powiedzieć wreszcie coś o świecie jego książek, który mimo groteskowego i gorzkiego kolorytu, domaga się przede wszystkim człowieczeństwa, że pisarz wyraża w ten sposób swoje błaganie o miłośćs ${ }^{39}$.

Dla węgierskiego krytyka postawa narratora, Istvána Tábori, nie jest tylko „artystyczną wizytówką", potwierdzającą kunszt literacki Kornisa, ale przede wszystkim gestem wyniesienia bohatera ponad "przed” i „po”. Język podania uwypukla istnienie mozaikowej, kosmicznej jedności, w której jest zawieszone niedoskonałe, pospolite [korcs] życie człowieka. "A w naszych czasach - pisze Pályi - charakterystyczną dolegliwością epoki jest uciekanie przed autentycznym istnieniem" 40 .

Tekst z 1981 roku ukazał się ponownie w 1992 roku. Pierwodruk i jego nieocenzurowana wersja różnią się zaledwie w kilku mało znaczących detalach, z wyjątkiem dwóch akapitów, które po latach autor zamknął znakami nawiasu: po 1989 roku te fragmenty tekstu wyglądają następująco:

(Szanowna Dyrekcjo: proszę tutaj - jeśli to tylko możliwe - żeby moich rodziców nie wywozić bydlęcym wagonem do obozu w Mauthausen, ponieważ wygląda na to, że mam szansę załatwić im miejsce w getcie na ulicy Dohány. Sobie życzę zesłania na prace przymusowe).

(Gdyby zaistniały tu kłopoty natury technicznej, z uwagi na to, że moja żona będzie miała ciut za mało wspólnego z sektorem prywatnym, niechże będzie mi wolno zwrócić szczególną uwagę Dyrekcji na osobę żony Józefa Csizmadiego, nazywaną Babirą. Śmiem twierdzić, że uda się ją nakłonić do napisania anonimowego listu, w którym poinformuje władzę, że moja żona terminowała przez sześć lat na ulicy Vörösmarty'ego w niższych klasach szkoły realnej w Zgromadzeniu Panien Szkockich, pozostając równocześnie, za sprawą Róży Klein, w ścisłych kontaktach z imperialistycznymi Stanami Zjednoczonymi Ameryki, skąd otrzymywała listy, czytała je i pisemnie na nie odpowiadała etc.).

Zamknięcie w nawias drugiego akapitu potraktować można jeszcze jako potrzebę uporządkowania wypowiedzi, podkreślenia poprzedzającego go zdania, które jest bezsprzecznie kluczowe w tym podpunkcie składanego podania. Takie interpunkcyjne zasygnowanie pierwszego akapitu zmienia jednak rangę wypowiedzi. Wywiezienie bydlęcym wagonem do obozu w Mauthausen i ewentualna

\footnotetext{
39 A. Pályi, Kornis Mihály. Végre élsz. „Jelenkor” 1981, nr 12, s. 1151-1152.

${ }^{40}$ Ibidem, s. 1152.
} 
alternatywa - przebywanie $\mathrm{w}$ getcie na ulicy Dohány - stają się w tym zapisie informacjami zmarginalizowanymi, podawanymi jedynie celem wyjaśnienia, dookreślenia wcześniejszych próśb i roszczeń. Ten artystyczny gest można by odczytać jako przejaw literackiej niepewności, niewiary $\mathrm{w}$ znaczenie tego kluczowego wydarzenia, które jest najtrudniejszym z wyliczanych w Podaniu doświadczeń. Być może Kornis w taki sposób wyobraża sobie artykułowanie milczenia o wydarzeniach, dla których nie ma stosownego miejsca $\mathrm{w}$ węgierskiej świadomości?

Artykułowanie milczenia, które ma utrzymać pozory antyrewizyjnego postępowania wobec historii staje się dla Kornisa wyzwaniem, które - dzięki wykorzystaniu formy i struktury oraz zawartości tekstu - pozwala nazywać, odsłaniać i demaskować prawdziwe oblicze systemu. W wielkiej, ale nieobecnej, bo toczącej się tylko w niejawnych, konceptualnych formach literackich, debacie o Zagładzie, najważniejsze wydają się postulaty Jánosa Kőbányai, który pierwszy zauważył, że „Holokaust to tekst” czy też „Holokaust jest tekstem”. Może zatem lepiej, że odtwarzanie doświadczenia granicznego odbywa się w obrębie materii literackiej. Znakomite rozwiązania formalne twórców zajmujących się tematem Zagłady udowadniają, że narzędzia artystyczne znane dotąd jako język ezopowy, mogą zyskać nową, zaskakującą płaszczyznę funkcjonalności. Może właśnie dlatego György Haraszti bez wahania mówi o prawdziwym "żydowskim renesansie" w życiu publicznym na Węgrzech po 1989 roku. Pozostaje jednak pytanie o siłę literatury. Czy zdoła ona przywrócić temat Zagłady? Czy pamięć o wydarzeniach w największym stopniu modelujących tożsamość i świadomość bohaterów oraz autorów trzeba będzie brać $\mathrm{w}$ nawias? 